\title{
Risk screening of the potential invasiveness of non-native freshwater fishes in the River Ob basin (West Siberian Plain, Russia)
}

\author{
Elena Interesova ${ }^{1,2,3} \cdot$ Lorenzo Vilizzi $^{4} \cdot$ Gordon H. Copp ${ }^{4,5,6,7}$
}

Received: 8 January 2020 / Accepted: 11 April 2020 / Published online: 23 May 2020

(C) The Author(s) 2020

\begin{abstract}
To inform regional managers of potentially invasive non-native (NN) freshwater fishes in the principal hydrosystem that drains the West Siberian Plain, the River Ob basin, 31 extant and potential future NN fish species were screened using the Aquatic Species Invasiveness Screening Kit (AS-ISK) with respect to current and projected future climate conditions. Calibration of the AS-ISK scores, using receiver operating characteristic curve analysis, identified 'basic risk assessment' and 'climate change assessment' threshold scores of 27.5 and 34.75 , respectively, with which to distinguish species that pose a high risk of being invasive in the $\mathrm{Ob}$ basin and those that pose a low-to-medium risk. Of the species screened, 12 ranked as high risk (black bullhead Ameiurus melas, brown bullhead Ameiurus nebulosus, grass carp Ctenopharyngodon idella, common carp Cyprinus carpio, eastern mosquitofish Gambusia holbrooki, silver carp Hypophthalmichthys molitrix, oriental weatherfish Misgurnus anguillicaudatus, rainbow trout Oncorhynchus mykiss, Chinese (Amur) sleeper Perccottus glenii, topmouth gudgeon Pseudorasbora parva, brown trout Salmo trutta, pikeperch Sander lucioperca and rudd Scardinius erythrophthalmus). The remaining species ranked as medium or low risk. Although the risk scores increased in $68 \%$ of species under climate change conditions, this affected the risk rankings of only two species: Salmo trutta decreased in rank from high to medium and Sander lucioperca increased in rank from medium to high. The outcomes of the present study, which identified 12 species for which full risk assessments are recommended, serves to inform the development of NN species policy and management in Russia.
\end{abstract}

Keywords AS-ISK $\cdot$ Risk identification $\cdot$ Climate change $\cdot$ Decision-support tools $\cdot$ Asia

Communicated by Anne Bousquet-Melou

Electronic supplementary material The online version of this article (https://doi.org/10.1007/s10113-020-01644-3) contains supplementary material, which is available to authorized users.

Gordon H. Copp

gcopp@bournemouth.ac.uk; gordon.copp@cefas.co.uk

1 Tomsk State University, Tomsk, Russia

2 Institute of Systematics and Ecology of Animals, Siberian Branch of the Russian Academy of Sciences, Novosibirsk, Russia

3 Novosibirsk Branch of Russian Federal Research Institute of Fisheries and Oceanography, Novosibirsk, Russia

4 Department of Ecology and Vertebrate Zoology, Faculty of Biology and Environmental Protection, University of Łódź, Lodz, Poland

5 Centre for Ecology, Environment and Sustainability, Bournemouth University, Poole, Dorset, UK

6 Centre for Environment, Fisheries \& Aquaculture Science, Lowestoft, UK

7 School of the Environment, Trent University, Peterborough, Ontario, Canada

\section{Introduction}

The West Siberian Plain is a region characterised by high native biodiversity (Solomeshch 2005) and aboriginal culture conservation value (Klubnikin et al. 2000), but threatened by indirect and direct human impacts, including climate change, habitat destruction and non-native (NN) species introductions. This is due to a lack of, or inadequately implemented, regional environmental management (Khitun and Rebristaya 2002). Over time, this has resulted in the region's main drainage basin, the River Ob, receiving several NN species introductions without assessment of their potential impacts on the region's native species and ecosystem nor their ecosystem services. And although there exists clear-cut evidence of highly adverse impacts by some invasive fish species (e.g. common carp Cyprinus carpio; Vilizzi et al. 2015), the threats posed by most invasive NN fishes remain largely unstudied (e.g. Crivelli 1995; Bogutskaya et al. 2001; Caiola and de Sostoa 2005; Sagoff 2005). This is especially notable for endemic 
fishes of various regions across Europe (Kalogianni et al. 2014; Clavero et al. 2015; Glamuzina et al. 2017).

For river systems with high (or potentially unknown) endemism, it is essential to carry out a risk screening process to identify which $\mathrm{NN}$ fishes are likely to become invasive in the risk assessment (RA) area in question as well as to identify gaps in knowledge (Almeida et al. 2013; Simonović et al. 2013; Perdikaris et al. 2016; Piria et al. 2016). Assessment of NNS impacts on endemic fishes is due in large part to the limited knowledge of the environmental biology of many species, and this is particularly true for the West Siberian Plain (Bogutskaya et al. 2001; Romanov et al. 2017), where native fishes have been, or will be, affected by climate warming (Reist et al. 2006), habitat destruction (Klubnikin et al. 2000) and NN species introductions (e.g. Popov 2009; Interesova 2012, 2016). Such a risk screening study is needed for the $\mathrm{Ob}$ basin - a geographically extensive drainage basin that has at least one endemic fish species (Bogutskaya et al. 2001). However, given their later post-glacial colonisation by fishes, Siberian rivers such as the $\mathrm{Ob}$ are not expected to have as high a level of endemism as the later-colonised rivers of Western Europe (e.g. Iberia and Greece: Reyjol et al. 2007). That said, the taxonomic status of some of the known native freshwater fish species $(n=41)$ in the Ob basin (Popov 2009) requires further study (Dyldin et al. 2017; Levin et al. 2017; Romanov et al. 2017), potentially resulting in a revised list of endemic species in the near future. Of the $22 \mathrm{NN}$ species of fish listed for Siberia, 17 have established self-sustaining populations in the $\mathrm{Ob}$ basin, which represents $\approx 32 \%$ of all fish species.

Most of the NN fishes in the $\mathrm{Ob}$ basin were intentionally introduced (mainly for fishery enhancement), though some arrived accidentally as contaminants of authorised consignments of commercially valuable fish species. The vectors and pathways by which some of these NN fishes were introduced to the $\mathrm{Ob}$ basin remain largely unknown, though aquaculture and aquarium trade are both currently growing industries in Siberia, with an increasing number of NN fishes being imported. This increases the risks of $\mathrm{NN}$ fish introductions to the $\mathrm{Ob}$ basin, with their dispersal facilitated by the network of connected canals and reservoirs existing since the end of the 2000s that link the catchments of the rivers $\mathrm{Ob}$ and Volga, e.g. the rivers Miass and Ufa (Korlyakov and Nokhrin 2014).

Projections of future climate in Siberia for the end of the twenty-first century indicate temperature increases that are expected to be more pronounced in the cold season (up by $+8{ }^{\circ} \mathrm{C}$ at higher latitudes) and less so in the warm season (up by $+5{ }^{\circ} \mathrm{C}$ in southern Siberia) (Groisman et al. 2013). The potential effects of climate change on Arctic freshwater systems, and specifically the River $\mathrm{Ob}$, are projected to be important at both local and basin scales (Prowse et al. 2006a). Indeed, the River $\mathrm{Ob}$ and its major tributary, the River Irtysh, are collectively considered a good example of the 'worst-case scenario' that would develop under future, warmer climate conditions due to the rivers being fed by poorly oxygenated groundwater on elevated contaminant inputs (Prowse et al. 2006b). Non-native fishes are another major form of 'biopollution' in Siberia that can affect native species and ecosystems (Popov 2009), and no risk analysis has been undertaken to identify their potential current and future impacts.

To address this lack of assessment of the potential adverse impacts of NN species on native species and ecosystems of the Ob basin, the aim of the present study was to identify which of the $\mathrm{NN}$ fishes in the $\mathrm{Ob}$ basin are likely to be invasive under current and predicted future climate conditions, which could contribute further to their wider dispersal. The outcome of this risk screening, which represents the first step in the NN species risk analysis process, will inform environmental managers and policymakers as to which NN species of fish warrant more comprehensive risk assessment. As such, the present study represents a crucial contribution towards the development of management strategies for $\mathrm{NN}$ fishes and to the implementation of management and conservation measures for native fishes and associated fisheries of the West Siberian region This approach has the potential for wider application to other regions of Russia.

\section{Study area, material and methods}

The West Siberian Plain, which is the largest peatland in the world (Keddy et al. 2009), has been described as the world's largest unbroken lowland (area $\approx 2.6-2.7$ million $\mathrm{km}^{2}$ ), comprising about one-third of Siberia, with $>50 \%$ being below $100 \mathrm{~m}$ a.s.l. The Plain extends $2400 \mathrm{~km}$ from the Arctic Ocean to the foothills of the Altay Mountains in the South, and $1900 \mathrm{~km}$ from the Ural Mountains in the West to the River Yenisei in the East - it is comprised of eight distinct vegetation regions (tundra, forest-tundra, northern taiga, middle taiga, southern taiga, sub-taiga forest, forest-steppe and steppe), which are drained by the River $\mathrm{Ob}$ and its major tributary, the River Irtysh (https://en.wikipedia.org/wiki/Ob_River). The $\mathrm{Ob}$ basin, the RA area in the present study, represents the longest river system in Northern Asia $(5410 \mathrm{~km} ; \approx 3$ million $\mathrm{km}^{2}$ ), crossing the climate zones 'cold semi-arid', 'humid continental' and 'sub-arctic'. During its passage through Russia, Kazakhstan and China, the River Ob traverses temperate mountains, steppe, continental forest, boreal mountains, coniferous forest and tundra woodland, as well as polar ecological zones.

Each of the geographic regions of the West Siberian Plain possesses a specific ichthyofauna (Popov 2009), which as mentioned includes 17 established NN species of fish of which seven have formed local, self-reproducing populations in the $\mathrm{Ob}$ basin. However, none of these species has yet undertaken 
natural spread, i.e. bighead carp Aristichthys nobilis, vendace Coregonus albula, grass carp Ctenopharyngodon idella, silver carp Hypophthalmichthys molitrix, channel catfish Ictalurus punctatus, bigmouth buffalo Ictiobus cyprinellus, European smelt Osmerus eperlanus and brown trout Salmo trutta. Whereas, the other nine established NN species of fish have begun to spread more widely, i.e. common bream Abramis brama, bleak Alburnus alburnus, Cyprinus carpio, sunbleak Leucaspius delineatus, Nikolsky's loach Misgurnus nikolskyi, Chinese (Amur) sleeper Perccottus glenii, topmouth gudgeon Pseudorasbora parva, southern ninespine stickleback Pungitius platygaster and pikeperch Sander lucioperca (Interesova 2016). Notably, Pseudorasbora parva and Pungitius platygaster arrived in the $\mathrm{Ob}$ basin from neighbouring regions, having been initially recorded in the River Ishim (part of the River Irtysh basin) and most likely migrated through the Nura-Ishim canal, which was constructed in the early 1970s. The other five NN species of fish that have failed to establish include: black buffalo Ictiobus niger, black carp Mylopharyngodon piceus and chum salmon Oncorhynchus keta - these species have not recently been found in water bodies of Western Siberia, whereas pink (humpback) salmon Oncorhynchus gorbuscha and rainbow trout Oncorhynchus mykiss have been reported in some waters of the $\mathrm{Ob}$ basin, but with no evidence to date of their ability to reproduce in the wild.

\section{Risk screening}

In total, $31 \mathrm{NN}$ freshwater fish species were screened for their potential invasiveness in the RA area using the Aquatic Species Invasiveness Screening Kit (AS-ISK), which is available for free download at www.cefas.co.uk/nns/tools/ (Copp et al. 2016a). The AS-ISK is the next-generation decisionsupport tool of FISK, the freshwater Fish Invasiveness Screening Kit (Copp et al. 2009; Lawson Jr et al. 2013), which was adapted from the Weed Risk Assessment (WRA) of Pheloung et al. (1999). The AS-ISK was created by combining the questions from the generic screening module of the European Non-native Species in Aquaculture Risk Analysis Scheme (Copp et al. 2016b), which were adapted from the FISK v1 questions (Copp et al. 2009), within the architecture of the FISK v2 (Lawson Jr et al. 2013). In doing so, AS-ISK questions were formulated to comply with the 'minimum standards' (Roy et al. 2018) for the assessment of NN species under EC Regulation No. 1143/2014 on the prevention and management of the introduction and spread of invasive alien species (Council of the European Communities 2014). Similar to the FISK, which has been used globally (Vilizzi et al. 2019), applications of the AS-ISK include risk screenings of NN freshwater fishes for RA areas in China ( $\mathrm{Li}$ et al. 2017), Great Britain (Dodd et al. 2019), Turkey (Tarkan et al. 2017a, b) and the southern Balkans (Glamuzina et al. 2017), of NN marine species for the Arabian/Persian Gulf and Sea of Oman (Clarke et al. 2020), for the coastal waters of southwestern Anatolia (Bilge et al. 2019), South Korea (Uyan et al. 2020) and of NN jellyfishes in the Mediterranean Sea (Killi et al. 2020).

Like the WRA and the FISK, the AS-ISK consists of 49 basic questions that examine the biogeographical and biological aspects of the taxon being screened, resulting in a Basic Risk Assessment (BRA) score. The AS-ISK has an additional six Climate Change Assessment (CCA) questions that require the assessor to evaluate how future climatic conditions are likely to affect the BRA score with regard to the risks of the taxon's introduction, establishment, dispersal and impact, resulting in a (combined) BRA + CCA score. To achieve a valid AS-ISK assessment, the assessor is required to provide for each question: a response, a justification for that response and a confidence rank for that response (see below). These three elements ensure that assessor responses are supported, where possible, by bibliographic sources and an explanation of their confidence in each response, which is a reflection of the available knowledge with which to answer the question. The resulting BRA score ranges from -20 to 68 , and the BRA + CCA score from -32 to 80 . Confidence in responses to questions are ranked using a $1-4$ scale $(1=$ low; $2=$ medium; $3=$ high; $4=$ very high) as per the Intergovernmental Panel on Climate Change (IPCC 2005; Copp et al. 2016a).

Fish species were selected for screening according to the following criteria: (1) extant species - those already recorded in the RA area $(n=22)$; and (2) horizon species, including (2a) potential entry via aquaculture $(n=4),(2 \mathrm{~b})$ existing in nearby river basins $(n=3)$ and $(2 \mathrm{c})$ currently sold in aquarium/pet shops $(n=2)$ (Table 1). Assessments were carried out by the first author, who is knowledgeable in the environmental biology of the fish species of the RA area, with GHC and LV overseeing construction of the species list and quality control of the generated AS-ISK database of assessments, respectively. Whilst replicated assessments (i.e. from two or more assessors) would have been preferable, this was not possible in the present study due to logistic constraints. However, risk assessments by a single assessor are not uncommon, both in the case of risk screenings (Vilizzi et al. 2019) and of full risk assessments (e.g. various assessments for Great Britain: www. nonnativespecies.org/index.cfm?pageid=143).

\section{Statistical analysis}

Following computation of the BRA and BRA + CCA scores, receiver operating characteristic (ROC) curve analysis (Bewick et al. 2004) was used to assess the predictive ability of AS-ISK to discriminate between NN freshwater fish 
Table 1 Non-native freshwater fish species screened with the Aquatic Species Invasiveness Screening Kit (AS-ISK) for the River Ob basin. Provided for each species is the selection criterion (Crit.) (1, extant species; horizon species: $2 a$, potential entry via aquaculture; $2 b$, existing in nearby river basins; $2 c$, currently sold in aquarium/pet shops); the a priori invasiveness (Inv.) categorisation ( $N$, non-invasive; $Y$, invasive); the Basic Risk Assessment (BRA) and BRA plus Climate Change Assessment (BRA + CCA) scores with corresponding risk outcomes; the difference (Delta) between BRA + CCA and BRA scores. The confidence level (CL) and the confidence factor (CF) (see text for explanation) is given for all questions (Total) and separately for the BRA and CCA components of the risk assessment. Risk outcomes are based on a threshold of 27.5 for the BRA (low: score within interval [20,1[; medium [1, 27.5[; high ]27.5, 68]) and of 34.75 for the BRA + CCA (low [-32, 1[; medium [1, 34.75[; high ]34.75, 80]), using the statistically appropriate brackets (']' and '[') to present the intervals (see www.mathwords.com/i/interval_notation.htm). The receiver operating characteristic curves are given in Fig. 1 and the combined AS-ISK reports are given in Supplementary Table S1

\begin{tabular}{|c|c|c|c|c|c|c|c|c|c|c|c|c|c|c|}
\hline \multirow[b]{3}{*}{ Species name } & \multirow[b]{3}{*}{ Common name } & \multirow[b]{3}{*}{ Crit. } & \multirow[b]{3}{*}{ Inv. } & \multicolumn{4}{|c|}{ Assessment component } & \multirow[b]{3}{*}{ Delta } & \multicolumn{6}{|c|}{ Confidence } \\
\hline & & & & \multicolumn{2}{|l|}{ BRA } & \multicolumn{2}{|c|}{$\mathrm{BRA}+\mathrm{CCA}$} & & \multicolumn{3}{|l|}{$\mathrm{CL}$} & \multicolumn{3}{|l|}{$\mathrm{CF}$} \\
\hline & & & & Score & Outcome & Score & Outcome & & Total & BRA & $\mathrm{CCA}$ & Total & BRA & CCA \\
\hline Abramis brama & common bream & 1 & $\mathrm{~N}$ & 27.0 & Medium & 33.0 & Medium & 6.0 & 3.0 & 3.1 & 2.8 & 0.76 & 0.77 & 0.71 \\
\hline Alburnus alburnus & bleak & 1 & $\mathrm{Y}$ & 25.0 & Medium & 31.0 & Medium & 6.0 & 2.9 & 3.0 & 2.5 & 0.74 & 0.75 & 0.63 \\
\hline Ameiurus melas & black bullhead & $2 \mathrm{a}$ & $\mathrm{Y}$ & 39.5 & High & 51.5 & High & 12.0 & 2.8 & 2.8 & 2.7 & 0.70 & 0.71 & 0.67 \\
\hline Ameiurus nebulosus & brown bullhead & $2 \mathrm{a}$ & $\mathrm{Y}$ & 35.0 & High & 47.0 & High & 12.0 & 2.9 & 3.0 & 2.8 & 0.74 & 0.74 & 0.71 \\
\hline Aristichthys nobilis & bighead carp & 1 & $\mathrm{Y}$ & 22.5 & Medium & 32.5 & Medium & 10.0 & 2.9 & 2.9 & 3.3 & 0.73 & 0.72 & 0.83 \\
\hline Coregonus albula & vendace & 1 & $\mathrm{~N}$ & 20.0 & Medium & 10.0 & Medium & -10.0 & 2.8 & 2.9 & 2.0 & 0.71 & 0.73 & 0.50 \\
\hline $\begin{array}{l}\text { Ctenopharyngodon } \\
\quad \text { idella }\end{array}$ & grass carp & 1 & $\mathrm{Y}$ & 42.5 & High & 54.5 & High & 12.0 & 3.1 & 3.1 & 3.0 & 0.77 & 0.77 & 0.75 \\
\hline Cyprinus carpio & common carp & 1 & $\mathrm{Y}$ & 37.5 & High & 49.5 & High & 12.0 & 3.0 & 3.0 & 3.0 & 0.75 & 0.76 & 0.75 \\
\hline Gambusia holbrooki & eastern mosquitofish & $2 \mathrm{c}$ & $\mathrm{Y}$ & 35.0 & High & 47.0 & High & 12.0 & 3.1 & 3.1 & 3.0 & 0.78 & 0.78 & 0.75 \\
\hline $\begin{array}{l}\text { Hypophthalmichthys } \\
\text { molitrix }\end{array}$ & silver carp & 1 & $\mathrm{Y}$ & 36.5 & High & 48.5 & High & 12.0 & 3.1 & 3.1 & 3.0 & 0.77 & 0.78 & 0.75 \\
\hline Ictalurus punctatus & channel catfish & 1 & $\mathrm{Y}$ & 25.0 & Medium & 33.0 & Medium & 8.0 & 2.7 & 2.7 & 2.3 & 0.66 & 0.67 & 0.58 \\
\hline Ictiobus cyprinellus & bigmouth buffalo & 1 & $\mathrm{~N}$ & 20.0 & Medium & 30.0 & Medium & 10.0 & 2.5 & 2.5 & 2.2 & 0.61 & 0.62 & 0.54 \\
\hline Ictiobus niger & black buffalo & 1 & $\mathrm{~N}$ & 12.5 & Medium & 22.5 & Medium & 10.0 & 2.5 & 2.5 & 2.5 & 0.62 & 0.62 & 0.63 \\
\hline Leucaspius delineatus & sunbleak & 1 & $\mathrm{~N}$ & 21.0 & Medium & 31.0 & Medium & 10.0 & 2.9 & 3.0 & 2.8 & 0.74 & 0.74 & 0.71 \\
\hline Leuciscus aspius & asp & $2 b$ & $\mathrm{~N}$ & 25.0 & Medium & 25.0 & Medium & 0.0 & 2.9 & 3.0 & 2.0 & 0.73 & 0.76 & 0.50 \\
\hline $\begin{array}{l}\text { Misgurnus } \\
\quad \text { anguillicaudatus }\end{array}$ & Oriental weatherfish & $2 \mathrm{c}$ & $\mathrm{Y}$ & 34.5 & High & 46.5 & High & 12.0 & 2.8 & 2.8 & 2.8 & 0.70 & 0.70 & 0.71 \\
\hline Misgurnus nikolskyi & Nikolsky's loach & 1 & $\mathrm{~N}$ & 23.5 & Medium & 33.5 & Medium & 10.0 & 2.7 & 2.7 & 2.8 & 0.68 & 0.67 & 0.71 \\
\hline $\begin{array}{l}\text { Mylopharyngodon } \\
\text { piceus }\end{array}$ & black carp & 1 & $\mathrm{Y}$ & 17.0 & Medium & 27.0 & Medium & 10.0 & 2.7 & 2.7 & 2.8 & 0.69 & 0.68 & 0.71 \\
\hline $\begin{array}{l}\text { Oncorhynchus } \\
\text { gorbuscha }\end{array}$ & pink (humpback) salmon & 1 & $\mathrm{Y}$ & 12.0 & Medium & 12.0 & Medium & 0.0 & 2.7 & 2.8 & 2.0 & 0.68 & 0.70 & 0.50 \\
\hline Oncorhynchus keta & chum salmon & 1 & $\mathrm{~N}$ & 7.5 & Medium & 17.5 & Medium & 10.0 & 2.6 & 2.7 & 2.0 & 0.66 & 0.68 & 0.50 \\
\hline Oncorhynchus mykiss & rainbow trout & 1 & $\mathrm{Y}$ & 44.0 & High & 40.0 & High & -4.0 & 3.1 & 3.2 & 2.2 & 0.78 & 0.81 & 0.54 \\
\hline Osmerus eperlanus & European smelt & 1 & $\mathrm{~N}$ & 11.0 & Medium & 11.0 & Medium & 0.0 & 2.7 & 2.8 & 2.2 & 0.68 & 0.70 & 0.54 \\
\hline Perccottus glenii & Chinese (Amur) sleeper & 1 & $\mathrm{Y}$ & 41.0 & High & 53.0 & High & 12.0 & 3.2 & 3.2 & 3.2 & 0.80 & 0.81 & 0.79 \\
\hline Pseudorasbora parva & topmouth gudgeon & 1 & $\mathrm{Y}$ & 36.5 & High & 48.5 & High & 12.0 & 2.8 & 2.8 & 3.0 & 0.70 & 0.69 & 0.75 \\
\hline Pungitius platygaster & $\begin{array}{l}\text { southern ninespine } \\
\text { stickleback }\end{array}$ & 1 & $\mathrm{~N}$ & 6.5 & Medium & 12.5 & Medium & 6.0 & 2.7 & 2.7 & 2.5 & 0.66 & 0.67 & 0.63 \\
\hline Salmo trutta & brown trout & 1 & $\mathrm{Y}$ & 35.0 & High & 27.0 & Medium & -8.0 & 2.9 & 3.0 & 2.0 & 0.73 & 0.76 & 0.50 \\
\hline Salvelinus fontinalis & brook trout & $2 \mathrm{a}$ & $\mathrm{Y}$ & 27.0 & Medium & 21.0 & Medium & -6.0 & 3.0 & 3.1 & 2.2 & 0.75 & 0.77 & 0.54 \\
\hline Salvelinus namaycush & lake trout & $2 \mathrm{a}$ & $\mathrm{Y}$ & 20.0 & Medium & 14.0 & Medium & -6.0 & 2.9 & 3.0 & 2.2 & 0.73 & 0.75 & 0.54 \\
\hline Sander lucioperca & pikeperch & 1 & $\mathrm{Y}$ & 28.0 & High & 36.0 & High & 8.0 & 2.8 & 2.9 & 2.5 & 0.71 & 0.72 & 0.63 \\
\hline $\begin{array}{l}\text { Scardinius } \\
\quad \text { erythrophthalmus }\end{array}$ & rudd & $2 \mathrm{~b}$ & $\mathrm{Y}$ & 44.0 & High & 44.0 & High & 0.0 & 2.8 & 2.9 & 2.5 & 0.70 & 0.71 & 0.63 \\
\hline Squalius cephalus & chub & $2 b$ & $\mathrm{~N}$ & 26.0 & Medium & 26.0 & Medium & 0.0 & 2.7 & 2.7 & 2.7 & 0.67 & 0.67 & 0.67 \\
\hline
\end{tabular}

species posing a high risk and those posing a medium or low risk of being invasive for the RA area. For ROC analysis to be implemented, species need to be categorised a priori in terms of their documented invasiveness (i.e. non-invasive or 
invasive). To this end, a priori categorisation for invasiveness was based on a four-step approach: (i) similar to previous ASISK applications to fish (cited here above), a preliminary search was made of FishBase (www.fishbase.org) for any reference to the species' threat to humans, with the species categorised a priori as invasive if listed as 'potential pest' and as non-invasive if listed as 'harmless'; (ii) if the species was listed as either 'not evaluated' or was absent in the above database, then a search was made of the Global Invasive Species Database (GISD: http://issg.org/database/welcome/ aboutGISD.asp), with the species categorised a priori as invasive if listed therein; (iii) if the species was absent from the GISD, then an additional search was made of the continental/country-level lists for invasive species in Africa, Asia, Europe and North America, whereby the species was categorised a priori as invasive if listed therein; finally, (iv) if the species was absent from any of the previous databases, then a Google Scholar (literature) search was performed to check whether at least one peer-reviewed reference in support for the species' invasiveness was found. The latter was then taken as 'sufficient evidence' for categorising the species a priori as invasive; whereas if no evidence was found, then the species was categorised a priori as non-invasive. Notably, in case a species was listed as harmless in FishBase, but found to be invasive in any of the other steps of the process, then the species was categorised a priori as invasive.

A ROC curve is a graph of sensitivity vs $1-$ specificity (or alternatively, sensitivity vs specificity) for each threshold value, where in the present context, sensitivity and specificity will be the proportion of a priori invasive and non-invasive species, respectively, that are correctly identified by AS-ISK as such. A measure of the accuracy of the calibration analysis is the area under the curve (AUC), which typically ranges from 0.5 to 1.0 , and the closer to 1.0 , the better the ability to differentiate between invasive and non-invasive species. If the AUC is equal to 1.0, then the test is $100 \%$ accurate, because both sensitivity and specificity are 1.0, and there are neither 'false positives' (a priori non-invasive species classified as high risk, hence invasive) nor 'false negatives' (a priori invasive species classified as low risk, hence non-invasive). Conversely, if the AUC is equal to 0.5 , then the test is $0 \%$ accurate as it cannot discriminate between 'true positives' (a priori invasive species classified as high risk, hence invasive) and 'true negatives' (a priori non-invasive species classified as low risk, hence non-invasive).

Following ROC curve analysis, the best AS-ISK threshold value that maximises the true positives rate and minimises the false positives rate was determined using Youden's $J$ statistic, whereas a 'default' threshold of 1 was set to distinguish between low-risk and medium-risk species. ROC curve analysis was carried out with package pROC (Robin et al. 2011) for R x64 v3.2.0 (R Development Core Team 2018) using 2000 bootstrap replicates for the confidence intervals of specificities, which were computed along the entire range of sensitivity points (i.e. 0 to 1 , at 0.1 intervals). The threshold intervals are presented using the statistically appropriate brackets (']' and '['; www.mathwords.com/i/interval_ notation.htm).

Based on the confidence level (CL) allocated to each response (see Risk screening), a confidence factor (CF) is obtained as:

$\mathrm{CF}=\sum\left(\mathrm{CL}_{\mathrm{Q} i}\right) /(4 \times 55)(i=1, \ldots, 55)$

where $\mathrm{CL}_{\mathrm{Q} i}$ is the confidence level for $\mathrm{Q} i, 4$ is the maximum achievable value for confidence (i.e. very high: see above) and 55 is the total number of questions comprising the AS-ISK questionnaire. The CF ranges from a minimum of 0.25 (i.e. all 55 questions with confidence level equal to 1) to a maximum of 1 (i.e. all 55 questions with confidence level equal to 4). Two additional confidence factors were also computed, namely the $\mathrm{CF}_{\mathrm{BRA}}$ and the $\mathrm{CF}_{\mathrm{CCA}}$, respectively based on the 49 Qs comprising the BRA and the six Qs comprising the CCA.

Differences between mean $\mathrm{CL}$ for the BRA $\left(\mathrm{CL}_{\mathrm{BRA}}\right)$ and for the CCA $\left(\mathrm{CL}_{\mathrm{CCA}}\right)$ were tested by permutational ANOVA based on a one-factor design (i.e. component, with two levels: BRA and CCA) (note that testing of the same differences for the CF leads to the same results as the two measures differ only by a constant). Analysis was carried out in PERMANOVA+ for PRIMER v6, with normalisation of the data and using a Bray-Curtis dissimilarity measure, 9999 unrestricted permutations of the raw data (Anderson et al. 2008), and with statistical effects evaluated at $\alpha=0.05$.

\section{Results}

The ROC curve for the BRA scores resulted in an AUC of $0.8614(0.7350-0.987795 \% \mathrm{CI})$ and that for the BRA + CCA scores in an AUC of $0.8273(0.6839-0.970695 \% \mathrm{CI})$ (Fig. 1a, b). These AUCs were well above 0.5, indicating that AS-ISK was able to discriminate reliably between noninvasive (low-to-medium risk) and invasive (high risk) NN freshwater fishes for the RA area. Youden's J provided thresholds of 27.5 for the BRA and 34.75 for the BRA + CCA, which were used for calibration of risk outcomes. Accordingly, species within the calibrated BRA score threshold interval $[1,27.5$ [ ranked as posing a medium risk of becoming invasive in the RA area, and those attributed scores within the interval $] 27.5,68]$ ranked as posing a high risk. The BRA + CCA score threshold distinguished between mediumrisk (score interval [1.0, 34.75[) and high-risk species (score interval $] 34.75,80]$ ). Whereas, species classified as low risk were those with BRA scores within $[-20,1[$ and BRA + CCA scores within $[-32,1[$. 

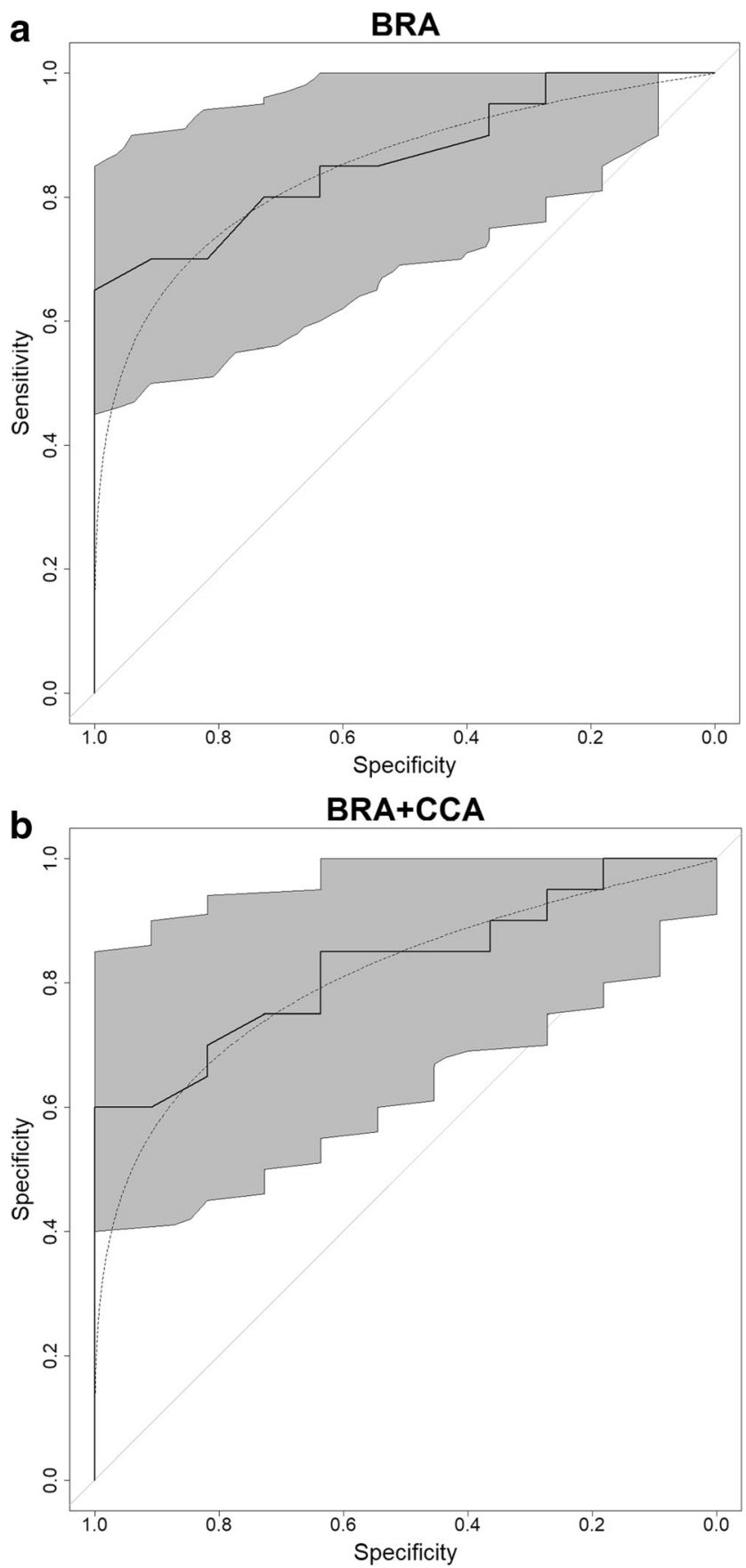

Fig. 1 Receiver operating characteristic curves for the assessment scores attributed to NN fish species screened for the River Ob basin (Table 1) using the Aquatic Species Invasiveness Screening Kit (AS-ISK): a BRA, scores from the Basic Risk Assessment (solid line); and b BRA + CCA, scores from the BRA plus Climate Change Assessment. Smoothing line and confidence intervals of specificities (grey area), which were computed (using 2000 bootstrap replicates) along the entire range of sensitivity points (i.e. 0 to 1 , at 0.1 intervals), are also provided

Of the 31 freshwater fishes screened, based on both the BRA and BRA + CCA thresholds, 12 (38.7\%) were classified as high risk and $19(61.3 \%)$ as medium risk. Amongst the species categorised a priori as invasive, 12 were true positives. Of the 19 medium-risk species, eleven were categorised a priori as non-invasive and eight as invasive (Table 1; see Supplementary information Table S1 for the species AS-ISK screening reports).

In the BRA, the highest-scoring species (score $\geq 40$, chosen as the 'very high' risk 'sub-threshold') were Oncorhynchus mykiss, rudd Scardinius erythrophthalmus, Ctenopharyngodon idella and Perccottus glenii, from higher to lower score. In the BRA + CCA (scores $\geq 46$ ), this was true of the latter two species, but also for (in decreasing score) black bullhead Ameiurus melas, Cyprinus carpio, Pseudorasbora parva, Hypophthalmichthys molitrix, brown bullhead Ameiurus nebulosus, eastern mosquitofish Gambusia holbrooki and oriental weatherfish Misgurnus anguillicaudatus (Table 1).

The CCA resulted in an increase in risk ranking relative to the BRA score for $21(67.7 \%)$ of the screened species, in a decrease in risk ranking for five $(16.1 \%)$, and in no change for the remaining five (16.1\%). Notably, all species classified as very high risk for the BRA + CCA also achieved the largest possible (positive) change in score of 12 (Table 1).

The CL values were the following: $\mathrm{CL}=2.85 \pm 0.03 \mathrm{SE}$ (all $55 \mathrm{Qs}$ ), $\mathrm{CL}_{\mathrm{BRA}}=2.89 \pm 0.03 \mathrm{SE}$ and the $\mathrm{CL}_{\mathrm{CCA}}=2.56$ $\pm 0.07 \mathrm{SE}$ (hence, in all cases indicating medium-to-high confidence). The $\mathrm{CL}_{\mathrm{BRA}}$ was significantly higher than the $\mathrm{CL}_{\mathrm{CCA}}$ $\left(F^{\#}{ }_{1,60}=13.16, P<0.001 ; \#=\right.$ permutational value $)$. Similarly, mean values for CF (all $55 \mathrm{Qs}=0.713 \pm 0.008$ $\mathrm{SE})$ and $\mathrm{CF}_{\mathrm{BRA}}(0.722 \pm 0.009 \mathrm{SE})$ were higher than the mean value for the $\mathrm{CF}_{\mathrm{CCA}}(0.641 \pm 0.018 \mathrm{SE})$, and the mean $\mathrm{CF}_{\mathrm{BRA}}$ was significantly higher than the mean $\mathrm{CF}_{\mathrm{CCA}}$ (same significance values as for the $\mathrm{CL}_{\mathrm{BRA}}$ vs $\mathrm{CL}_{\mathrm{CCA}}$ comparison due to the two indices being related). In all cases, the narrow standard errors indicated overall similarity in CLs and CFs across the species screened.

\section{Discussion}

Of the NN freshwater fishes screened for the River Ob basin, $42 \%$ were classified as posing a high-to-very-high risk of being invasive, and all of these species have also attracted highrisk screening scores for RA areas in southern regions of Europe (FISK: Simonović et al. 2013; Perdikaris et al. 2016; Piria et al. 2016) and Asia (AS-ISK: Li et al. 2017; Tarkan et al. 2017a, b), whereas other species (i.e. Ctenopharyngodon idella, Hypophthalmichthys molitrix, Oncorhynchus mykiss) were classified by FISK as medium risk in Southern Finland (Puntila et al. 2013), and some of these medium-risk species have been identified as posing medium- and moderately-high invasiveness risk in other RA areas. For example, Aristichthys nobilis and Ictalurus punctatus received higher risk rankings for the $\mathrm{Ob}$ basin than elsewhere. Similarly, Abramis brama and Sander lucioperca, both ranked as 'medium risk' in the present study, were classified as 'medium-to-high risk' for other RA areas with both FISK (Simonović et al. 2013; 
Perdikaris et al. 2016; Piria et al. 2016) and AS-ISK (Li et al. 2017; Tarkan et al. 2017a, b). Of these two, Abramis brama has also received an AS-ISK high-risk ranking as a translocated species for those parts of Great Britain where the species is not native (Dodd et al. 2019). The differences in risk rankings of $\mathrm{NN}$ fishes in the $\mathrm{Ob}$ basin relative to other RA areas may be associated with the broader range of environmental conditions in the $\mathrm{Ob}$ basin. Also, species that have been introduced, but have not yet established self-sustaining populations, achieved lower risk rankings.

Of the highest BRA scoring species in the present study, only Perccottus glenii has established self-reproducing populations and begun to spread widely across the $\mathrm{Ob}$ basin. Following its appearance in the mid-1970s via an unknown introduction vector and pathway (Reshetnikov and Chibilev 2009), P. glenii was predicted to expand its range across the Holarctic region (Reshetnikov and Ficetola 2011). Consistent with this, the species has spread rapidly and is now widespread throughout the region (Reshetnikov et al. 2017) and considered to be one of the most invasive freshwater fishes in Russia (Dgebuadze et al. 2018). Despite the lack of documented evidence of current impacts on ecosystems of the Ob basin, $P$. glenii is thought to be responsible for a decline in the abundance of macro-invertebrates and amphibian larvae in small water bodies (Reshetnikov and Chibilev 2009).

Other species with high BRA scores included those not yet reported for the $\mathrm{Ob}$ basin (i.e. Ameiurus melas, Ameiurus nebulosus, Ctenopharyngodon idella, Gambusia holbrooki, Misgurnus anguillicaudatus, Oncorhynchus mykiss and Scardinius erythrophthalmus). Of these, C. idella and O. mykiss are of aquaculture interest in Siberia, but currently, there is no evidence of self-sustaining populations in the wild. Ctenopharyngodon idella and P. glenii are the two highest (i.e. risk) scoring species under future climate conditions. Ctenopharyngodon idella was first introduced in the $\mathrm{Ob}$ basin (Novosibirsk Reservoir) in 1958, into Bukhtarma Reservoir in 1968, and in the early 1970s into the Irtysh-Karaganda canal, lakes in the south of Western Siberia (e.g. Ubinskoye and Sartlan) and into the Belovsky Reservoir (River Inya, rightbank tributary of the Ob). Currently, $C$. idella has selfsustaining populations in Belovsky Reservoir only, where water is warmer as a result of heated water effluents (Tskhai et al. 2001). In addition, C. idella is currently farmed and sometimes caught in natural waters, probably as escapees from fish farms. Overall, C. idella can exert potentially negative impacts on the recipient ecosystems by over-consuming aquatic vegetation, which serves as a spawning substratum for native phytophilic fish species and as a refuge for their juvenile fishes and for amphibians.

Of the medium-risk NN species, five have established and spread within the $\mathrm{Ob}$ basin, six have formed self-reproducing populations at certain locations only, one is present but without evidence of natural reproduction, and seven of them are horizon species. Many of these medium-risk species attracted AS-ISK scores near the upper limit of the medium-risk category (i.e. the threshold between medium- and high-risk species). Four of these high-scoring, medium-risk species are dispersing more widely in the $\mathrm{Ob}$ basin, predominantly by natural means, i.e. Abramis brama, Alburnus alburnus, Leucaspius delineatus and Misgurnus nikolskyi. Whereas, another two of these species (Ictalurus punctatus and Aristichthys nobilis) are established in one or a few locations only, with no evidence of wider dispersal within the West Siberian Plain.

Of particular concern is the potential effect of future climate conditions on potential invasiveness; this led to increased risk scores (i.e. BRA + CCA) in $68 \%$ of the screened species (Table 1), which suggests that more than half of the existing and potential future $\mathrm{NN}$ species are likely to pose an increased risk of being invasive under the future, warmer climatic conditions predicted for the $\mathrm{Ob}$ basin (Groisman et al. 2013). Notably, the species for which AS-ISK scores decreased, and thus their relative risk, were all salmonids. However, these climate-related increases in AS-ISK score resulted in changes of risk ranking (low, medium, high) in two species only (Table 1): Salmo trutta decreased in rank from high to medium and Sander lucioperca increased in rank from medium to high. The confidence levels for these assessments were higher for the BRA scores than for the BRA + CCA scores, which is not surprising given the uncertainty associated with climate forecasting (Mehta et al. 2019).

In conclusion, the present risk screening study has highlighted several gaps in knowledge with respect to both native and $\mathrm{NN}$ fish species in the $\mathrm{Ob}$ basin. The process of dispersal of NN fish species in the West Siberian Plain is currently being monitored, but documented data on the adverse impacts (ecological, socio-economic, ecosystem services) exerted by $\mathrm{NN}$ fishes remain scarce if not entirely lacking. In particular, little is known of the species' population dynamics, especially their population size and reproductive status in the $\mathrm{Ob}$ basin. Even less is known of socioeconomic impacts that invasive $\mathrm{NN}$ fishes could cause and how this could affect the ecosystem services provided by the Ob basin's fishery resources to the various regions of the West Siberian Plain. The notable decrease in assessor confidence in their responses to the climate change (CCA) questions highlights an even greater uncertainty of how NN fishes will respond to the warmer climate and the projected increased runoff due to increased precipitation during winter and reduced river discharges in summer (Reist et al. 2006). The outcomes of the present study provide essential information for regional environmental managers, in particular the identification of high-risk species (13 under current and 12 under future climate conditions) for which full risk assessments are recommended (Table 1). As such, the present study serves to inform the process of developing effective $\mathrm{NN}$ fish species policy, 
legislation and management in the various geographical regions of the West Siberian Plain and, ultimately, to other regions across Russia.

Funding information The participation of GHC was supported by Cefas' Science Excellence fund as part of its contribution to the ICES WGITMO ToR to undertake a global trial of the AS-ISK. Studies of non-native freshwater fishes in the River Ob were conducted whilst fulfilling government orders from the Ministry of Education and Science of the Russian Federation (Projects Ministry of Education and Science of the Russian Federation No. 5.4004.2017/4.6). These were financially supported by the Russian Foundation for Basic Research (RFBR) grant No. 18-00-01493 КОМФИ (KOMFI).

Open Access This article is licensed under a Creative Commons Attribution 4.0 International License, which permits use, sharing, adaptation, distribution and reproduction in any medium or format, as long as you give appropriate credit to the original author(s) and the source, provide a link to the Creative Commons licence, and indicate if changes were made. The images or other third party material in this article are included in the article's Creative Commons licence, unless indicated otherwise in a credit line to the material. If material is not included in the article's Creative Commons licence and your intended use is not permitted by statutory regulation or exceeds the permitted use, you will need to obtain permission directly from the copyright holder. To view a copy of this licence, visit http://creativecommons.org/licenses/by/4.0/.

\section{References}

Almeida D, Ribeiro F, Leunda PM, Vilizzi L, Copp GH (2013) Effectiveness of FISK, an invasiveness screening tool for nonnative freshwater fishes, to perform risk identification assessments in the Iberian Peninsula. Risk Anal 33:1404-1413. https://doi.org/ 10.1111/risa. 12050

Anderson MJ, Gorley RN, Clarke KR (2008) PERMANOVA for PRIMER: guide to software and statistical methods. PRIMER-E Ltd, Plymouth

Bewick V, Cheek L, Ball J (2004) Statistics review 13: receiver operating characteristic curves. Crit Care 8:508-512. https://doi.org/10.1186/ $\operatorname{cc} 3000$

Bilge G, Filiz H, Yapıcı S, Tarkan AS, Vilizzi L (2019) A risk screening study on the potential invasiveness of Lessepsian fishes in the southeastern coasts of Anatolia. Acta Ichthyol Piscat 49:23-31. https:// doi.org/10.3750/AIEP/02422

Bogutskaya NG, Naseka AM, Komlev AM (2001) Freshwater fishes of Russia: preliminary results of the fauna revision. Proceedings ZIN 289:39-50 (in Russian)

Caiola N, de Sostoa A (2005) Possible reasons for the decline of two native toothcarps in the Iberian Peninsula: evidence of competition with the introduced eastern mosquitofish. J Appl Ichthyol 21:358 363. https://doi.org/10.1111/j.1439-0426.2005.00684.x

Clarke SA, Vilizzi L, Lee L, Wood LE, Cowie WJ, Burt JA, Mamiit RJ, Ali H, Davison PI, Fenwick GV, Harmer R, Skóra M, Kozic S, Aislabie LR, Kennerley A, Le Quesne W, Copp GH, Stebbing PD (2020) Identifying potentially invasive non-native marine and brackish water species for the Arabian Gulf and Sea of Oman. Glob Chang Biol. https://doi.org/10.1111/gcb.14964

Clavero M, Esquivias J, Qninba A, Riesco M, Calzada J, Ribeiro F, Fernández N, Delibes M (2015) Fish invading deserts: non-native species in arid Moroccan rivers. Aquatic Conserv: Mar Freshw Ecosyst 25:49-60. https://doi.org/10.1002/aqc.2487
Copp GH, Vilizzi L, Mumford JD, Fenwick GV, Godard MJ, Gozlan RE (2009) Calibration of FISK, an invasive-ness screening tool for nonnative freshwater fishes. Risk Anal 29:457-467. https://doi.org/10. 1111/j.1539-6924.2008.01159.x

Copp GH, Vilizzi L, Tidbury H, Stebbing PD, Tarkan AS, Miossec L, Goulletquer P (2016a) Development of a generic decision-support tool for identifying potentially invasive aquatic taxa: AS-ISK. Manag Biol Invasions 7:343-350. https://doi.org/10.3391/mbi. 2016.7.4.04

Copp GH, Godard MJ, Russell IC, Gherardi F, Tricarico E, Miossec L, Goulletquer P, Almeida D, Britton JR, Vilizzi L, Mumford J, Williams C, Reading A, Rees EMA, Merino-Aguirre R (2016b) European Non-native Species in Aquaculture Risk Analysis Scheme-a summary of assessment protocols and decision support tools for use of alien species in aquaculture. Fish Manag Ecol 23:111. https://doi.org/10.1111/fme.12076

Crivelli AJ (1995) Are fish introductions a threat to endemic freshwater fishes in the northern Mediterranean region? Biol Conserv 72:311319. https://doi.org/10.1016/0006-3207(94)00092-5

Dgebuadze YY, Petrosyan VG, Khlyap LA (eds) (2018) The most dangerous invasive species of Russia (TOP-100). KMK Scientific Press, Moscow ISBN 978-5-907099-53-1 (in Russian)

Dodd JA, Vilizzi L, Bean CW, Davison PI, Copp GH (2019) At what spatial scale should risk screenings of translocated freshwater fishes be undertaken-river basin district or climo-geographic designation? Biol Conserv 230:122-130. https://doi.org/10.1016/j.biocon.2018. 12.002

Dyldin YV, Hanel L, Romanov VI, Plesnik J (2017) Review of the genus Thymallus (Pisces: Salmoniformes, Salmonidae, Thymallinae) with taxonomic notes. Bull Lampetra ZO ČSOP Vlašim 8:103-126 ISBN: 978-80-87964-15-6

European Union (2014) Regulation (EU) No 1143/2014 of the European Parliament and of the Council of 22 October 2014 on the prevention and management of the introduction and spread of invasive alien species. OJ L 317:35-55. http://eur-lex.europa.eu/legal-content/EN/ TXT/?uri=OJ:JOL_2014_317_R_0003 Last accessed: 2 Apr 2020

Glamuzina B, Tutman $\bar{P}$, Nikolić $\bar{V}$, Vidović Z, Pavličević J, Vilizzi L, Copp GH, Simonović P (2017) Comparison of taxon-specific and taxon-generic risk screening tools to identify potentially invasive non-native fishes in the River Neretva catchment (Bosnia and Herzegovina and Croatia). River Res Appl 33:670-679. https:// doi.org/10.1002/rra.3124

Groisman PY, Blyakharchuk TA, Chernokulsky AV, Arzhanov MM, Marchesini L, Bogdanova EG, Borzenkova II, Bulygina ON, Karpenko AA, Karpenko LV, Knight RW, Khon VC, Korovin GN, Meshcherskaya AV, Mokhov II, Parfenova EI, Razuvaev VN, Speranskaya NA, Tchebakova NM, Vygodskaya NN (2013) Climate changes in Siberia. In: Groisman PY, Gutman G (eds) Regional environmental changes in Siberia and their global consequences. Springer Environmental Science and Engineering. Springer, Dordrecht, pp 57-109 ISBN 978-94-007-4569-8

Interesova EA (2012) Belica Leucaspius delineatus (Cyprinidae) in waterbodies of southwest Siberia. J Ichthyol 52:356-361. https:// doi.org/10.1134/S0032945212020051

Interesova EA (2016) Alien fish species in the Ob River basin. Russ J Biol Invasions 7:156-167. https://doi.org/10.1134/ S2075111716020089

IPCC (2005) Guidance notes for lead authors of the IPCC fourth assessment report on addressing uncertainties. Intergovernmental Panel on Climate Change, WMO \& UNEP. https://wg1.ipcc.ch/publications/ supportingmaterial/uncertainty-guidance-note.pdf Last accessed: 2 Apr 2020

Kalogianni E, Giakoumi S, Andriopoulou A, Chatzinikolaou Y (2014) Prey utilisation and trophic overlap between the non native mosquitofish and a native fish in two Mediterranean rivers. Mediterr Mar Sci 15:287-301. https://doi.org/10.12681/mms.609 
Keddy PA, Fraser LH, Solomeshch AI, Junk WJ, Campbell DR, Arroyo MT, Alho CJ (2009) Wet and wonderful: the world's largest wetlands are conservation priorities. BioScience 59:39-51. https://doi. org/10.1525/bio.2009.59.1.8

Khitun O, Rebristaya O (2002) Anthropogenic impacts on habitat structure and species richness in the West Siberian Arctic. In: Watson AE, Alessa L, Sproull J (eds) Wilderness in the Circumpolar North: searching for compatibility in ecological, traditional, and ecotourism values; 15-16 May 2001, Anchorage, AK. Proceedings RMRS-P26. Ogden, UT: U.S. Department of Agriculture, Forest Service, Rocky Mountain Research Station. pp 85-95

Killi N, Tarkan AS, Kozic S, Copp GH, Davison PI, Vilizzi L (2020) Risk screening of the potential invasiveness of non-native jellyfishes in the Mediterranean Sea. Mar Pollut Bull 150:110728. https://doi.org/ 10.1016/j.marpolbul.2019.110728

Klubnikin K, Annett C, Cherkasova M, Shishin M, Fotieva I (2000) The sacred and the scientific: traditional ecological knowledge in Siberian river conservation. Ecol Appl 10:1296-1306. https://doi. org/10.1890/1051-0761(2000)010[1296:TSATST]2.0.CO;2

Korlyakov KA, Nokhrin DYu (2014) Trends in the emergence of the Volga-Ob invasive corridor. Bulletin of the Council of Young Scientists and Specialists of the Chelyabinsk Region 2014(2):19-28

Lawson LL Jr, Hill JE, Vilizzi L, Hardin S, Copp GH (2013) Revisions of the Fish Invasiveness Screening Kit (FISK) for its application in warmer climatic zones, with particular reference to peninsular Florida. Risk Anal 33:1414-1431. https://doi.org/10.1111/j.15396924.2012.01896.x

Levin BA, Simonov EP, Ermakov OA, Levina MA, Interesova EA, Kovalchuk OM, Malinina YA, Mamilov NS, Mustafajev NJ, Pilin DV, Pozdeev IV, Prostakov NI, Roubenyan HR, Titov SV, Vekhov DA (2017) Phylogeny and phylogeography of the roaches, genus Rutilus (Cyprinidae), at the eastern part of its range as inferred from mtDNA analysis. Hydrobiologia 788:33-46. https://doi.org/10. 1007/s10750-016-2984-3

Li S, Chen J, Wang X, Copp GH (2017) Invasiveness screening of nonnative fishes for the middle reach of the Yarlung Zangbo River, Tibetan Plateau, China. River Res Appl 33:1439-1444. https://doi. org/10.1002/rra.3196

Mehta L, Adam HN, Srivastava S (2019) Unpacking uncertainty and climate change from 'above'and 'below'. Reg Environ Chang 19: 1529-1532. https://doi.org/10.1007/s10113-019-01539-y

Perdikaris C, Koutsikos N, Vardakas L, Kommatas D, Simonović P, Paschos I, Detsis V, Vilizzi L, Copp GH (2016) Risk screening of non-native, translocated and traded aquarium freshwater fishes in Greece using the Fish Invasiveness Screening Kit. Fish Manag Ecol 23:32-43. https://doi.org/10.1111/fme.12149

Pheloung PC, Williams PA, Halloy SR (1999) A weed risk assessment model for use as a biosecurity tool evaluating plant introductions. J Environ Manag 57:239-251. https://doi.org/10.1006/jema.1999. 0297

Piria M, Povž M, Vilizzi L, Zanella D, Simonović P, Copp GH (2016) Risk screening of non-native freshwater fishes in Croatia and Slovenia using the Fish Invasiveness Screening Kit. Fish Manag Ecol 23:21-31. https://doi.org/10.1111/fme.12147

Popov PA (2009) Species composition and pattern of fish distribution in Siberia. J Ichthyol 49:483-495. https://doi.org/10.1134/ S0032945209070017

Prowse TD, Wrona FJ, Reist JD, Hobbie JE, Lévesque LM, Vincent WF (2006a) General features of the Arctic relevant to climate change in freshwater ecosystems. AMBIO 35:330-339. https://doi.org/10. 1579/0044-7447(2006)35[330:GFOTAR]2.0.CO;2

Prowse TD, Wrona FJ, Reist JD, Gibson JJ, Hobbie JE, Lévesque LM, Vincent WF (2006b) Climate change effects on hydroecology of Arctic freshwater ecosystems. AMBIO 35:347-359. https://doi. org/10.1579/0044-7447(2006)35[347:CCEOHO]2.0.CO;2
Puntila R, Vilizzi L, Lehtiniemi M, Copp GH (2013) First application of FISK, the Freshwater Fish Invasiveness Screening Kit, in Northern Europe: example of Southern Finland. Risk Anal 33:1397-1403

R Core Team (2018) R: a language and environment for statistical computing. R Foundation for Statistical Computing, Vienna www.Rproject.org/

Reist JD, Wrona FJ, Prowse TD, Power M, Dempson JB, King JR, Beamish RJ (2006) An overview of effects of climate change on selected Arctic freshwater and anadromous fishes. AMBIO 35:381388. https://doi.org/10.1579/0044-7447(2006)35[381:AOOEOC]2. $0 . \mathrm{CO} ; 2$

Reshetnikov AN, Chibilev EA (2009) Distribution of the fish rotan (Perccottus glenii dybowski, 1877) in the Irtysh River basin and analysis of possible consequences for environment and people. Contemp Probl Ecol 3:224-228. https://doi.org/10.1134/ S1995425509030102

Reshetnikov AN, Ficetola GF (2011) Potential range of the invasive fish rotan (Perccottus glenii) in the Holarctic. Biol Invasions 13:29672980. https://doi.org/10.1007/s10530-011-9982-1

Reshetnikov AN, Golubtsov AS, Zhuravlev VB, Lomakin SL, Rezvyi AS (2017) Range expansion of rotan Perccottus glenii, sunbleak Leucaspius delineatus, and bleak Alburnus alburnus in the $\mathrm{Ob}$ River basin. Contemp Probl Ecol 6:612-620. https://doi.org/10. 1134/S1995425517060105

Reyjol Y, Hugueny B, Pont D, Bianco PG, Beier U, Caiola N, Casals F, Cowx IG, Economou A, Ferreira T, Haidvogl G (2007) Patterns in species richness and endemism of European freshwater fish. Glob Ecol Biogeogr 16:65-75. https://doi.org/10.1111/j.1466-8238.2006. 00264.x

Robin X, Turck N, Hainard A, Tiberti N, Lisacek F, Sanchez J-C, Müller M (2011) pROC: an open-source package for R and S+ to analyze and compare ROC curves. BMC Bioinformatics 12, 77. https://doi. org/10.1186/1471-2105-12-77

Romanov VI, Interesova EA, Dyldin YV, Babkina IB, Karmanova OG, Vorobiev DS (2017) An annotated list and current state of ichthyofauna of the middle Ob River basin. Int J Environ Stud 74:818-830. https://doi.org/10.1080/00207233.2017.1288547

Roy HE, Rabitsch W, Scalera R, Stewart A, Gallardo B, Genovesi P, Essl F, Adriaens T, Bacher S, Booy O, Branquart E, Brunel S, Copp GH, Dean H, D'hondt B, Josefsson M, Kenis M, Kettunen M, Linnamagi M, Lucy F, Martinou A, Moore N, Nentwig W, Nieto A, Pergl J, Peyton J, Roques A, Schindler S, Schönrogge K, Solarz W, Stebbing PD, Trichkova T, Vanderhoeven S, van Valkenburg J, Zenetos A (2018) Developing a framework of minimum standards for the risk assessment of alien species. J Appl Ecol 55:526-538. https://doi.org/10.1111/1365-2664.13025

Sagoff M (2005) Do non-native species threaten the natural environment? J Agric Environ Ethics 18:215-236. https://doi.org/10.1007/ s10806-005-1500-y

Simonović P, Tošić A, Vassilev M, Apostolou A, Mrdak D, Ristovska M, Kostov V, Nikolić V, Škraba D, Vilizzi L, Copp GH (2013) Risk assessment of non-native fishes in the Balkans region using FISK, the invasiveness screening tool for non-native freshwater fishes. Mediterr Mar Sci 14:369-376. https://doi.org/10.12681/mms.337

Solomeshch AI (2005) The West Siberian lowland (pp. 11-62). In: Fraser LH, Keddy PA (eds) The world's largest wetlands: ecology and conservation. Cambridge University Press, Cambridge. https://doi. org/10.1017/CBO9780511542091.003

Tarkan AS, Vilizzi L, Top N, Ekmekçi FG, Stebbing PD, Copp GH (2017a) Identification of potentially invasive freshwater fishes, including translocated species, in Turkey using the Aquatic Species Invasiveness Screening Kit (AS-ISK). Int Rev Hydrobiol 102:4756. https://doi.org/10.1002/iroh.201601877

Tarkan AS, Sarı HM, İlhan A, Kurtul I, Vilizzi L (2017b) Risk screening of non-native and translocated freshwater fish species in a Mediterranean-type shallow lake: Lake Marmara (West Anatolia). 
Zool Middle East 63:48-57. https://doi.org/10.1080/09397140. 2017.1269398

Tskhai AA, Poulin M, Beldeeva LN, Bezmaternykh DM, Ganoulis J, Zherelina IV, Kvon VI, Kirillov VV, Liakhova SA, Nachtnebel HP, Nechai NZ, Silantyeva MM (2001) In: Tskhai AA, Poulin M (eds) Ecological modeling introduction. Azbuka Publishing House, Barnaul ISBN 5-93957-006-2

Uyan U, Oh C-W, Tarkan AS, Top N, Copp GH, Vilizzi L (2020) Risk screening of the potential invasiveness of non-native marine fishes in South Korea. Mar Pollut Bull. https://doi.org/10.1016/j. marpolbul.2020.111018)

Vilizzi L, Tarkan AS, Copp GH (2015) Experimental evidence from causal criteria analysis for the effects of common carp Cyprinus carpio on freshwater ecosystems: a global perspective. Rev Fish
Sci Aquacult 23:253-290. https://doi.org/10.1080/23308249.2015. 1051214

Vilizzi L, Copp GH, Adamovich B, Almeida D, Chan J, Davison PI, Dembski S, Ekmekçi FG, Ferincz Á, Forneck SC, Hill JE, Kim JE, Koutsikos N, Leuven RSEW, Luna S, Magalhães F, Marr S, Mendoza R, Mourão CF, Neal JW, Onikura N, Perdikaris C, Piria M, Poulet N, Puntila R, Range IL, Simonović P, Ribeiro F, Tarkan AS, Troca DFA, Vardakas L, Verreycken H, Vintsek L, Weyl OLF, Yeo DCJ, Zeng Y (2019) A global review and meta-analysis of applications of the freshwater Fish Invasiveness Screening Kit. Rev Fish Biol Fish 29:529-568

Publisher's note Springer Nature remains neutral with regard to jurisdictional claims in published maps and institutional affiliations. 